\title{
Use of Amendments to Restore Ecosystem Function to Metal Mining-Impacted Sites: Tools to Evaluate Efficacy
}

\author{
Sally L. Brown ${ }^{1} \cdot$ Rufus L. Chaney ${ }^{2}$
}

Published online: 29 March 2016

(C) Springer International Publishing AG 2016

\begin{abstract}
As in situ use of amendments for restoration of metal-contaminated mining sites becomes increasingly accepted, the expected level of ecosystem function at these sites will increase. Use of appropriate tools to measure both the level and value of that function is critical to expand use of this approach. For these sites, amendment mixtures must reduce metal availability in situ and restore ecosystem function. Combinations of mixtures, typically consisting of a material with high metal binding capacity (cyclonic ashes, municipal biosolids, or other materials rich in $\mathrm{Fe}, \mathrm{Al}$, or $\mathrm{Mn}$ oxides), material to adjust soil $\mathrm{pH}$ (sugar beet lime, cement kiln dust, dolomitic limestone), and an organic residual to provide soil structure and nutrients (composts, animal manures, municipal biosolids) have been tested in multiple lab and field trials on metal-contaminated sites. This review focuses on field tests of this approach with the goal of providing methods to quantify reduction of hazard and restoration of functional systems. Methods to evaluate success of amendments including extractions to measure changes in metal availability, microbial function and diversity, phytoavailability of metals, and earthworm and small mammal assays are discussed. In most cases,
\end{abstract}

This article is part of the Topical Collection on Land Pollution

Sally L. Brown

slb@u.washington.edu

Rufus L. Chaney

Rufus.Chaney@ARS.USDA.GOV

1 School of Environmental and Forest Sciences, University of Washington, Box 352100, Seattle, WA 98195, USA

2 Crop Systems and Global Change Laboratory, Agricultural Research Service, USDA, Bldg. 007, BARC-West, Beltsville, MD 20705, USA measures of metal availability and ecosystem function are related. For example, surveys of small mammals on restored sites provide information on metal availability as well as suitability of restored habitat. Additional measures of ecosystem function including soil fertility, physical properties, and diversity of habitat are described. Finally, measures of the value of this approach for restoring ecosystems are detailed.

Keywords Metal mining wastes · Biosolids · Composts · Amendments $\cdot$ Ecosystem function $\cdot$ Bioavailability · Ecosystem services

\section{Introduction}

Mining and processing metal ores generates significant quantities of waste. The waste materials typically consist of a mixture of overburden, the mineral material overlying the ore deposit and tailings, and the residual material from mineral extraction. The level of contamination in these materials will depend on the efficiency of metal extraction. Aerial deposition of metals through smelter emissions and smelter slag are additional sources of contamination. These sites can impact significant area. For example, the Tri-State mining district in the USA includes portions of Kansas, Oklahoma, and Missouri [1]. Mining of $\mathrm{Pb}$ and $\mathrm{Zn}$ ores began in the mid-1800s with over 100 mines and 17 smelters in operation in Jasper County, MO during the peak of the mining operations. Metal-contaminated mine waste covers over 600,000 ha and the area includes multiple sites on the US EPA National Priorities List. Use of residual-based amendments to reduce metal availability in situ and restore ecosystem functions to these sites offers multiple benefits. However, it is necessary to identify appropriate combinations of amendments to reduce metal availability and reestablish ecosystem function. As part of this, determining 
appropriate tools to measure efficacy of amendments is critical. Amendments must reduce metal availability to a range of receptors. In addition, the amended substrate must demonstrate the ability to support diverse ecosystem functions such as nutrient cycling, water retention, carbon retention, and providing habitat for diverse groups of species of flora and fauna. This review discusses historic use of amendments to restore disturbed sites where lack of nutrients and poor physical properties were the primary obstacles preventing establishment of a selfsustaining cover. Two approaches to restoration of disturbed sites that are also metal contaminated: use of metal-tolerant cultivars to reestablish a plant cover and use of in situ soil amendments to reduce contaminant availability will be summarized. A combined approach, where amendments are used to both limit contaminant availability and restore soil function, is outlined. We refer to this as an ecosystems approach to restoration of metal-contaminated mine wastes as it considers both the reduction in metal availability and establishing a functional ecosystem. This ecosystems approach is the primary focus of this review. In order for this approach to be adopted, it is critical to provide appropriate tools to measure efficacy of amendment combinations. Field studies of amendments to restore metalcontaminated sites and the tools used to evaluate both reductions in metal availability and level of ecosystem function will be discussed. A final section discusses attempts to value the ecosystems that have been reestablished on these sites. Quantifying the value of these systems is likely to be critical in gaining larger-scale use of this approach.

\section{Historical Use of Amendments for Disturbed Soils}

Use of soil amendments for restoration of disturbed soils is a well-established practice [2-4]. Here, we are referring to cases such as surface mining or deposition of mining-related wastes where the removal or replacement of the surface soil horizon has resulted in a surface material that is incapable of supporting a self-sustaining plant cover. Examples include coal mining, borrow pits, and sand and gravel mines. Amendments used at these sites were typically high organic matter residuals including municipal biosolids, composts, animal manures, and pulp sludges as well as inorganic residuals including coal combustion byproducts, sugar beet lime, dredged materials, water treatment residues, aluminumprocessing residuals, and foundry sands. There are many examples in the research of different organic amendments being used to restore a vegetative cover to disturbed soils. Initial research on this approach had focused on the efficacy of this practice, including testing of different rates and types of amendments for lands disturbed by coal mining with limited work on sand, gravel, and other types of mines [3, 5-7]. In each of these cases, the primary impediments to establishment of a plant cover on the disturbed surface were poor physical properties and low nutrient status. Compared with the difficulty in remediating metal mining disturbed sites, these were comparatively simple infertile soils, but the prototype for problem solving of disturbed soils.

There was also work done to verify the safety of the practice from the perspective of the amendments used for restoration rather than any hazards posed by the substrate. As much of the work was begun with municipal biosolids prior to the 1993 regulations regarding metal concentrations [8], there was also research done on the availability of metals and nutrients added to the substrate with the biosolids to plants and groundwater [3,9-13]. Studies have typically shown minimal to no negative impact to groundwater or plants from metals added with biosolids. Spikes in nitrogen in groundwater have been observed following amendment addition. They are typically observed during the first year after amendment addition with concentrations decreasing over subsequent measurement intervals [13-15]. The addition of high carbon materials with biosolids or composts has also been shown to limit nutrient movement $[2,14]$. In addition to demonstrating the safety of this practice, these studies have generally shown that use of organic amendments has resulted in accelerated soil formation [16]. More rapid recovery has also been shown with use of residuals in comparison to topsoiling or chemical fertilization $[16,17]$. In addition, this approach has often resulted in high levels of ecosystem function on the treated soils. For example, restoration with amendments has allowed for a return of the disturbed lands to production agriculture with yields similar to those observed in undisturbed farmland [17-19]. This approach has become sufficiently accepted in parts of the USA that there is recommended guidance and/or regulations for types and application rates of amendments to disturbed lands $[4,8,20,21]$.

\section{Metal-Contaminated Sites}

\section{Phytostabilization}

Metal contamination can occur on agricultural soils, native soils, or soils in urban areas. In these cases, the ability of the soil to support a plant cover is not compromised. For surface residuals from metal mining-impacted areas, establishment of a self-sustaining plant cover requires reducing metal availability and restoring soil function. For these sites, the primary concern is a reduction in the phytoavailability and bioavailability of the contaminants and associated hazards to the ecosystem. In addition, typically, mining wastes are akin to subsoils with poor physical properties and with very low fertility. Phytostabilization is a term used to denote many approaches to using soil amendments and plants to alleviate the contaminant risk of contaminated soils including soils contaminated by metals. Initial efforts on these types of sites often focused 
on establishing a vegetative cover to stabilize the contaminated materials and so reduce hazards from wind and water erosion [22-26]. In many of the initial studies, work concentrated on identification of metal-tolerant plant species that are able to grow in a high metal substrate [27-30].

\section{Reducing Metal Availability}

A second or related approach has focused on reducing metal availability in situ using soil amendments so that plant growth on contaminated sites is not limited to tolerant species. A number of soil chemical mechanisms have been used. For example, phosphorus addition to $\mathrm{Pb}$-contaminated sites has been used to reduce the bioavailability associated with $\mathrm{Pb}$ in situ though the precipitation of pyromorphite $[31,32]$. There are also examples of high surface area oxides used to absorb $\mathrm{Pb}, \mathrm{Zn}$, and $\mathrm{Cd}$. For example, Vagronsveld et al. [24] noted the ability of cyclonic ashes (berengite) to reduce $\mathrm{Zn}, \mathrm{Cd}$, and $\mathrm{Pb}$ availability to plants and allow for a persistent vegetative cover for at least 12 years after amendment addition in a gold mine spoil in Portugal. This observed reduction in availability may be the result of oxide adsorption and potentially the formation of metal-layered double hydroxides. Spectroscopy has shown that in contaminated soils, $\mathrm{Zn}$ can precipitate as a component of double hydroxide mineral [33, 34]. Addition of high Fe biosolid composts to $\mathrm{Pb}$ and $\mathrm{As}$ co-contaminated sites resulted in increased association of both elements with Fe oxides [35]. Increasing soil $\mathrm{pH}$ will also reduce the availability of most metals although in calcareous systems, increased metal solubility may be observed as a result of displacement off of adsorption sites by soluble $\mathrm{Ca}$. These results suggest that using amendments to restore ecosystems to metal mining wastes will require an amendment or adjustment to reduce metal solubility.

\section{Ecological Approaches}

Most recently, phytostabilization has been combined with the use of amendments to establish a self-sustaining plant cover on metal-contaminated wastes by simultaneously reducing metal availability and restoring a functional soil to these sites. This has been referred to as the "ecological approach" (23 citing Jeffrey et al. 1975). In order for this approach to be successful, mechanisms for decreasing contaminant availability have to consider a range of potential pathways and receptors. Amendments also have to improve soil physical properties and fertility. In the same way that amendments restored productivity to disturbed soils, amendments have the potential to restore function to disturbed and contaminated soils, resulting in active systems both below and aboveground. With the return of plants and wildlife, it is critical to assure that the restored site does not become an attractive nuisance
[36]. In this approach, biological processes including nitrogen transformations, nutrient cycling, and decomposition are reestablished on the waste materials, transforming them into complex soil ecosystems. More recently advocates of this approach have suggested it as low cost, more sustainable and desirable alternatives to conventional remedial methods for metal-contaminated sites. Volchko et al. [37, 38] stress the importance of incorporating ecosystem function and the provision of ecosystem services into the consideration of remedial alternatives. Cundy et al. [39] describe gentle remediation options (GRO) as "techniques for contaminated sites that result in no gross reduction in soil functionality (or a net gain)." Munns et al. [40] note that the US EPA established a set of generic ecological assessment endpoints (GEAE) to the risk assessment process in 2003. These include receptors that are of high ecological relevance that are also susceptible to contaminants. This approach has recently been expanded to include ecosystem services with the focus on services that are beneficial to people. This addition is intended to complement the existing GEAE approach. It provides a way to directly link ecological risk to human well-being and, in the process, makes it easier to communicate the importance of this type of remedial approach. With this approach, it is required to define the direct benefit of the ecosystem service to people in order for it to be considered (Fig. 1).

\section{Use of Ecosystem Endpoints}

There are an increasing number of examples of research including greenhouse and field trials as well as full-scale use of amendments to both limit contaminant availability in situ and restore ecosystem functions. This approach has focused on combinations of amendments to achieve these goals. A number of different amendment combinations have been tested. A list of field trials including the nature and concentrations of the contaminants and amendments used is shown in Table 1. Evaluations of success of the amendment combinations have also expanded to include measures of ecosystem function as well as broader assessments of the bioavailability of metals in the treated materials. In each case, at least one combination of the amendments tested has demonstrated the efficacy of amendments to both reduce contaminant phytoavailability and bioavailability and to reestablish some level of ecosystem function to the sites.

In order for in situ amendment addition to provide longterm stabilization, it is critical to document that the sites are able to support functional ecosystems. For example, in a review of revegetation of mine tailings in arid environments, Mendez and Maier [26] set out soil, microbial, and plant criteria to evaluate success (Table 2). Ecosystems are complex with interrelated functions that are not fully understood or quantified. Understanding and quantifying the success of amendments to restore self-sustaining plant cover and 
Fig. 1 In situ restoration of alluvial tailings in Leadville, $\mathrm{CO}$ was used as a remedial alternative. Measures of ecosystem function were used to evaluate the efficacy of this approach [41]. The reestablishment of trout fishing on the river would qualify as an ecosystem service [40]
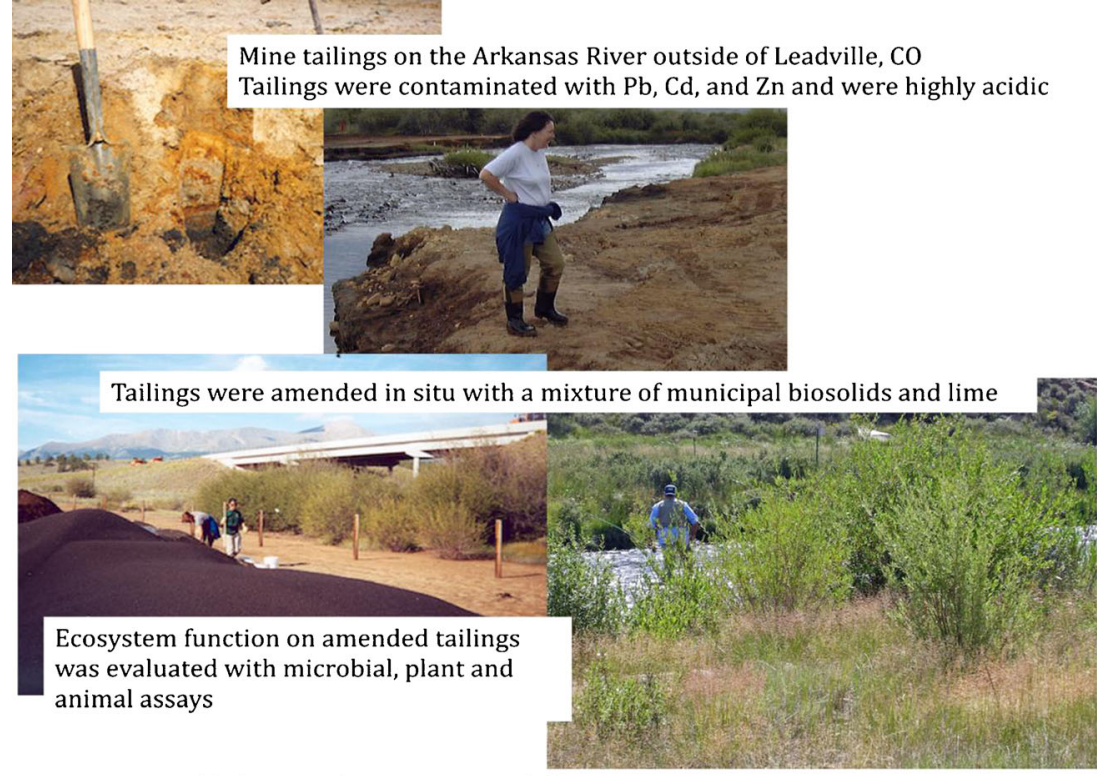

Re-establishment of an active trout fishing area constitutes an ecosystem service function to these sites has to occur on multiple levels. On the first level, it is essential to document a reduction in the availability of the contaminants [55]. As the contaminants can potentially impact a range of receptors, this is not always clearcut. On the next level, the remedies have to restore function to soils. This typically involves a consideration of the soils' ability to supply and recycle nutrients to plants as well as the physical properties of the substrate. Finally, it is increasingly important to document restoration of ecosystem functions to these sites. Here, definitions of functions and criteria to quantify function can vary based on site location, characteristics, and desired end use. Examples of functions include microbial assays, net primary productivity, and nutrient cycling [56]. In many cases, these different levels of measures can overlap. For example, measures of microbial diversity and activity can be considered to reflect ecosystem function but have also been used as a measure of reduction of contaminant bioavailability [41, 42, 49, 51, 57-59]. Examples of different measures used for each category are discussed below.

\section{Bioavailability Measures}

Bioavailability is the availability of elements to animals which ingest crops or contaminated soils, or soils/dusts which are inhaled by animals. Different measures have been used based on the scale of the study and targeted receptors. As contaminants are left in place, these measures cannot focus on total concentrations. In certain cases, tests to measure toxicity of waste materials such as the US EPA toxic characteristic leaching procedure test have been used to assess changes in availability of contaminants $[41,60]$. However, these extracts have not typically been developed to predict in situ toxicity and are not designed for a focus on ecosystem functions. For these sites and goals, it seems more appropriate to consider impacts of the contaminants to the range of potential receptors. The bioavailable fraction of the total concentration has to be the focus [55]. What portion of the total metal constitutes the bioavailable fraction can vary based on the targeted receptor. Chemical extracts of soils have traditionally been used to predict nutrient availability in soils. These are often aggressive as they attempt to mimic the behavior of plants that alter soil chemistry in order to increase nutrient solubility [61]. In contrast, dilute salt extracts of soils are frequently used to predict phytoavailable fractions of total metals in contaminated soils. Here, the extracts are designed to mimic soil solution. Table 3 lists different versions of these extracts used to measure bioavailable metals in the field trials on mining contaminated sites. Common extracts include deionized water [52-54] and $\mathrm{Ca}\left(\mathrm{NO}_{3}\right)_{2}$ [42-44]. Kumpiene et al. [62] used soils from different sites across Europe that had been treated using different GROs including plant-based phytoextraction, phytostabilization, and in situ stabilization to assess different chemical extracts to predict ecotoxicological responses. The best correlations were found with $\mathrm{NH}_{4} \mathrm{NO}_{3}$ and $\mathrm{NaNO}_{3}$ extractable trace elements and the ecotoxicological responses. Nitrate solutions avoid chloride complexation of $\mathrm{Cd}$ and some other elements by the extractants. Ecotoxicological responses were measured using plant growth and enzyme assays, earthworm preference tests, and nematode growth and reproduction tests. However, clear correlations were not found across extractions and assays for one of the soils where amendments had previously been shown to effectively reestablish vegetation with low metal uptake [52]. 
Table 1 Field studies that have tested the use of amendments to reduce metal bioavailability and reestablish ecosystem function on mining impacted soils

\begin{tabular}{|c|c|c|c|c|c|c|}
\hline Study & Time & Type & Location & Site type & $\begin{array}{l}\text { Contaminants } \\
\left(\mathrm{mg} \mathrm{kg}^{-1}\right)\end{array}$ & $\begin{array}{l}\text { Amendment } \\
\text { Rates at } \mathrm{t} \mathrm{ha}^{-1}\end{array}$ \\
\hline $\begin{array}{l}\text { Baker } \\
\quad \text { et al. [42] }\end{array}$ & $\begin{array}{l}2 \text { years post } \\
\text { amendment }\end{array}$ & $\begin{array}{l}\text { Small-scale } \\
\text { replicated plots }\end{array}$ & Kansas, USA & $\begin{array}{l}\text { Mine waste } \\
\text { materials_-primarily } \\
\text { overburden }\end{array}$ & $\begin{array}{l}\mathrm{Pb}(2300-3400) \\
\mathrm{Zn}(6200-6800)\end{array}$ & $\begin{array}{l}\text { Composted manure (45 and 269) } \\
\quad \pm \mathrm{CaCO}_{3} \text { and bentonite }\end{array}$ \\
\hline $\begin{array}{l}\text { Brown } \\
\text { et al. [43] }\end{array}$ & $\begin{array}{l}2 \text { years post } \\
\text { amendment }\end{array}$ & $\begin{array}{l}\text { Small-scale } \\
\text { replicated plots }\end{array}$ & Idaho, USA & $\mathrm{Pb}, \mathrm{Zn}$ mine waste & $\begin{array}{l}\mathrm{Cd} 13-82 \\
\mathrm{~Pb} 1100-8700 \\
\mathrm{Zn} 2500-19,100\end{array}$ & $\begin{array}{l}\text { Municipal biosolids, biosolid } \\
\text { compost, wood ash, pulp and } \\
\text { paper sludge, log yard debris in } \\
\text { various combinations }\end{array}$ \\
\hline $\begin{array}{l}\text { Brown } \\
\quad \text { et al. [41] }\end{array}$ & $\begin{array}{l}2 \text { years post } \\
\text { amendment }\end{array}$ & Large scale (>1 ha) & Colorado, USA & $\begin{array}{l}\text { Alluvial pyritic } \\
\mathrm{Pb}, \mathrm{Zn} \text { mine } \\
\text { tailings }\end{array}$ & $\begin{array}{l}\mathrm{Cd} 9.5-27 \\
\mathrm{~Pb} 1390-3170 \\
\mathrm{Zn} 1400-2520\end{array}$ & $\begin{array}{l}\text { Municipal biosolids (224) and lime } \\
\text { (224) }\end{array}$ \\
\hline $\begin{array}{l}\text { Brown } \\
\quad \text { et al. [44] }\end{array}$ & $\begin{array}{l}6 \text { and } 18 \text { months } \\
\text { post amendment }\end{array}$ & $\begin{array}{l}\text { Small scale } \\
\text { replicated plots }\end{array}$ & Oklahoma, USA & $\begin{array}{l}\mathrm{Pb}, \mathrm{Zn} \text { tailings and } \\
\text { overburden }\end{array}$ & $\begin{array}{l}\mathrm{Cd} 29 \\
\mathrm{~Pb} 4000 \\
\mathrm{Zn} 6830\end{array}$ & $\begin{array}{l}\text { Di-ammonium phosphate, biosolids, } \\
\text { compost, high Fe residuals, added } \\
\text { singly and in combination }\end{array}$ \\
\hline $\begin{array}{l}\text { Trlica and } \\
\quad \text { Brown [45] }\end{array}$ & $\begin{array}{l}5 \text { years post } \\
\text { amendment }\end{array}$ & $\begin{array}{l}\text { Small scale } \\
\text { replicated plots }\end{array}$ & Colorado, USA & $\begin{array}{l}\text { Alluvial pyritic } \\
\text { Pb, Zn mine } \\
\text { tailings }\end{array}$ & $\begin{array}{l}\mathrm{Cd} 11.2 \\
\mathrm{~Pb} 2060-4120 \\
\mathrm{Zn} 3370-3910\end{array}$ & $\begin{array}{l}\text { Lime kiln dust } 224 \text {, municipal } \\
\text { biosolids and woody material to } \\
\text { achieve } 25 \text { and } 50 \mathrm{~g} \text { kg organic } \\
\text { matter and } \mathrm{C} / \mathrm{N} \text { ratios from } 8-50: 1\end{array}$ \\
\hline Brown et al. [46] & $\begin{array}{l}\text { Up to } 7 \text { years post } \\
\text { amendment }\end{array}$ & $\begin{array}{l}\text { Small scale } \\
\text { replicated plots }\end{array}$ & Colorado, USA & $\begin{array}{l}\text { Alluvial pyritic } \\
\mathrm{Pb}, \mathrm{Zn} \text { mine } \\
\text { tailings }\end{array}$ & $\begin{array}{l}\mathrm{Cd} 75 \\
\mathrm{~Pb} 2600 \\
\mathrm{Zn} 6700\end{array}$ & $\begin{array}{l}\text { Different types of lime }\left(224 \mathrm{CaCO}_{3}\right. \\
\text { equivalent })+ \text { biosolids }(224)\end{array}$ \\
\hline Brown et al. [1] & Up to 13 years & $\begin{array}{l}\text { Large scale } \\
\qquad(>1 \text { ha })\end{array}$ & Missouri, USA & $\begin{array}{l}\mathrm{Pb} / \mathrm{Zn} \text { tailings } \\
\quad \text { and overburden }\end{array}$ & $\begin{array}{l}\text { Cd } 18-57 \\
\mathrm{~Pb} 1100-4900 \\
\mathrm{Zn} 3200-10,000\end{array}$ & $\begin{array}{l}\text { Biosolids } 110-336+\text { lime } 24-48 \text {, } \\
\text { mushroom compost } 224 \text {, poultry } \\
\text { manure } 224\end{array}$ \\
\hline $\begin{array}{l}\text { Cordova } \\
\text { et al. [47] }\end{array}$ & $\begin{array}{l}\text { 5-9 months post } \\
\text { amendment }\end{array}$ & $\begin{array}{l}\text { Small scale } \\
\text { replicated plots }\end{array}$ & Chile & Smelter contaminated & $\begin{array}{l}\mathrm{Cu} 194-607 \\
\mathrm{~Pb} 39-76 \\
\mathrm{Zn} 110-149\end{array}$ & $\begin{array}{l}\text { Lime (6.7), lime }(6.7)+\text { compost } \\
\quad(133) \text { each } \pm \text { planting }\end{array}$ \\
\hline $\begin{array}{l}\text { Friesl-Hanl } \\
\text { et al. [48] }\end{array}$ & $\begin{array}{l}5 \text { years post } \\
\text { amendment } \\
\text { addition }\end{array}$ & $\begin{array}{l}\text { Small scale } \\
\text { replicated plots }\end{array}$ & Austria & $\begin{array}{l}\text { Agricultural soils } \\
\text { contaminated by } \\
\text { smelter deposition }\end{array}$ & $\begin{array}{l}\text { As } 32 \\
\mathrm{Cd} 5.6 \\
\mathrm{~Pb} 913 \\
\mathrm{Zn} 545\end{array}$ & $\begin{array}{l}\text { Red mud } 1 \% w / w, \text { gravel } \\
\text { sludge }+ \text { red mud } 2.5+0.5 \% \\
w / w, \text { limestone } 0.5 \% w / w\end{array}$ \\
\hline $\begin{array}{l}\text { Galende } \\
\text { et al. [49] }\end{array}$ & $\begin{array}{l}6 \text { months post } \\
\text { amendment } \\
\text { addition }\end{array}$ & $\begin{array}{l}\text { Small scale } \\
\text { replicated plots }\end{array}$ & Spain & $\begin{array}{l}\text { Mine waste } \\
\text { materials-primarily } \\
\text { overburden }\end{array}$ & $\begin{array}{l}\mathrm{Pb} 28,380-46,635 \\
\mathrm{Zn} 25,774-71,139\end{array}$ & $\begin{array}{l}\text { Cow slurry, poultry manure compost, } \\
\text { pulp sludge mixed with poultry } \\
\text { manure }\end{array}$ \\
\hline $\begin{array}{l}\text { Madejón } \\
\text { et al. [50] }\end{array}$ & $\begin{array}{l}\text { Up to } 2 \text { years post } \\
\text { amendment }\end{array}$ & $\begin{array}{l}\text { Small-scale } \\
\text { replicated plots }\end{array}$ & Spain & $\begin{array}{l}\text { Tailings dam spill } \\
\text { onto agricultural soil }\end{array}$ & $\begin{array}{l}\text { As } 211 \\
\mathrm{Cd} 4.4 \\
\mathrm{Cu} 119 \\
\mathrm{~Pb} 471 \\
\mathrm{Zn} 381\end{array}$ & $\begin{array}{l}\text { Municipal biosolids compost }(2 \times 30) \text {, } \\
\text { a high humic acid low grade coal } \\
(2 \times 25)+\text { sugar been lime }(2 \times 10) \\
\text { and sugar beet lime }(2 \times 30)\end{array}$ \\
\hline $\begin{array}{l}\text { Pepper } \\
\quad \text { et al. [51] }\end{array}$ & Up to 10 years & Large scale (>1 ha) & Arizona, USA & Copper tailings & $\begin{array}{l}\text { Cu } 570-2500 \\
\text { Mo } 45-195\end{array}$ & $\begin{array}{l}\text { Municipal biosolids at 248, } 270 \\
\text { and } 371\end{array}$ \\
\hline $\begin{array}{l}\text { Stuczynski } \\
\text { et al. [52] }\end{array}$ & $\begin{array}{l}1-5 \text { years post } \\
\text { amendment } \\
\text { addition }\end{array}$ & Large scale (>1 ha) & Poland & Smelter wastes & $\begin{array}{l}\mathrm{Cd} 540 \\
\mathrm{~Pb} 7900 \\
\mathrm{Zn} 30,900 \\
\mathrm{Cd} 2310 \\
\mathrm{~Pb} 23,800 \\
\mathrm{Zn} 75,100\end{array}$ & $\begin{array}{l}\text { Municipal biosolids } 300+\text { lime } \\
\text { as mixed oxide and carbonate } \\
\text { at } 31 \text {, } \\
\text { Carbonate cap of } 30 \mathrm{~cm} \text { depth } \\
\text { with } 300 \text { biosolids applied } \\
\text { above the cap }\end{array}$ \\
\hline $\begin{array}{l}\text { Ulriksen } \\
\text { et al. [53] }\end{array}$ & $\begin{array}{l}7 \text { months post } \\
\text { amendment } \\
\text { addition }\end{array}$ & $\begin{array}{l}\text { Small-scale } \\
\text { replicated plots }\end{array}$ & Chile & $\begin{array}{l}\text { Aerial deposition } \\
\text { of smelter waste }\end{array}$ & $\begin{array}{l}\text { As } 32 \\
\mathrm{Cu} 291 \\
\mathrm{~Pb} 28 \\
\mathrm{Zn} 145\end{array}$ & $\begin{array}{l}\text { Lime (6.7), lime }(6.7)+\text { compost } \\
\quad(133) \text { each } \pm \text { planting }\end{array}$ \\
\hline $\begin{array}{l}\text { Vangronsveld } \\
\text { et al. [54] }\end{array}$ & $\begin{array}{l}5 \text { years post } \\
\text { amendment }\end{array}$ & $\begin{array}{l}\text { Large scale } \\
\qquad(>1 \text { ha })\end{array}$ & Belgium & Smelter waste & Zn 2000-16,000 & $\begin{array}{l}\text { Berengite (high Al residue from } \\
\text { coal combustion) }(120)+\text { MSW } \\
\text { compost (100) }\end{array}$ \\
\hline
\end{tabular}

Bioaccessibility is measured by a chemical method which has been shown to extract an amount of a contaminant which is well correlated with the bioavailability of the contaminant measured by an animal feeding trial. Soil extracts can also be designed to predict bioaccessibility to other receptors. An example is the physiologically based extraction test (PBET) procedure [32].
The PBET procedure was initially developed to predict the portion of total $\mathrm{Pb}$ in soils that would become soluble and is absorbed in the human gastrointestinal system, but versions of this extract have also been developed to predict metal toxicity to waterfowl $[32,63,64]$ and terrestrial birds [65]. It is important to note that much better correlation of bioaccessibility with 
Table 2 Criteria for evaluating successful in situ stabilization of mine wastes including tailings and overburden

\begin{tabular}{lll}
\hline Soil & Microbial & Plant \\
\hline $\begin{array}{l}\text { Improved } \\
\text { aggregation }\end{array}$ & $\begin{array}{c}\text { Increased population } \\
\text { of heterotrophic } \\
\text { bacteria and fungi } \\
\text { Decrease in } \\
\text { autotrophic iron and }\end{array}$ & $\begin{array}{c}\text { Shoot metal concentrations } \\
\text { acceptable for wildlife }\end{array}$ \\
$\begin{array}{c}\text { Reduction of } \\
\text { erosion and } \\
\text { runoff }\end{array}$ & $\begin{array}{c}\text { Biomass and percent cover } \\
\text { comparable to undisturbed } \\
\text { neighboring sites }\end{array}$ \\
$\begin{array}{c}\text { Reduced metal } \\
\text { bioavailability } \\
\text { and mobility }\end{array}$ & & Self propagation \\
& & $\begin{array}{c}\text { Colonized by native species } \\
\text { Plant cover and productivity } \\
\text { for }>10 \text { years }\end{array}$ \\
\hline
\end{tabular}

Adapted from Mendez and Maier [26]

mammalian bioavailability was demonstrated for $\mathrm{pH} 2.5$ than the EPA set $\mathrm{pH} 1.5$ for this extraction [32].

\section{Plant Response/Metal Uptake}

Plant metal uptake is one of the most accepted measures of metal availability. The majority of field trials included measures of plant metal concentrations as a means to demonstrate efficacy of the amendments in alleviating phytotoxicity (Table 3). Plant metal concentrations can reflect the potential for phytotoxicity but may also indicate potential for revegetation to pose hazards to wildlife that use the site for grazing [36, 52, 66]. Stuczynski et al. [52] specifically grew hay on the restored site for use in a feeding trial to determine whether the plants would pose a risk to wildlife or livestock grazing on the site. This study illustrates errors in risk prediction based on feeding $\mathrm{Cd}$ salt-amended diets to estimate dietary $\mathrm{Cd}$ risks. Crops grown on contaminated sites will contain high levels of $\mathrm{Zn}$ if $\mathrm{Cd}$ is increased because in $\mathrm{Zn}-\mathrm{Pb}$ mine wastes, $\mathrm{Zn}$ is commonly 100-200 times higher than Cd. In Stuczynski et al. [52], comparable levels of $\mathrm{Cd}$ were fed in control forage plus $\mathrm{Cd}$ salt as in the forage grown on the remediated site, but tissue $\mathrm{Cd}$ was markedly lower for the crop on remediated soil than for the control forage plus $\mathrm{Cd}$ salt. Feeding $\mathrm{Cd}$ salts strongly overestimates risk from crop $\mathrm{Cd}$ for nearly all contaminated sites. These results supported the findings of no increase in kidney or liver for the forages grown on the remediated smelter wastes. Similar results were shown for $\mathrm{Cd}$ in Swiss chard grown on soils amended with biosolids; crop Cd was increased significantly but kidney and liver $\mathrm{Cd}$ were not increased [67]. Other measures of metal availability or metal-induced stress to plants have been used. Vangronsveld et al.
[54] measured enzymes in plants as indicators of metal stress. This approach was recently tested as part of a method identification exercise for GROs [62]. Across a number of sites, the authors found that plant stress enzyme activity increased with increasing extractability of trace elements. Growth assays have also been used with soils collected from field trials [41, 62]. The advantages of greenhouse assays are that a single species can be used across multiple sites and that unique field conditions will not prevent growth. However, greenhouse trials can sometimes fail to predict field factors that can limit response. For example, in a field trial in Leadville, $\mathrm{CO}$, low rainfall, and associated elevated electrical conductivity prevented plant establishment over multiple field seasons, something that was not anticipated in the greenhouse trial that preceded the field work [46]. Greater salinity tolerance of plants seeded, or irrigation after amendment of extreme acidity may be required at some sites [26].

\section{Microbial Function}

Increasingly, measures of microbial function are being used to evaluate reductions in metal availability and ecosystem function in amended sites. Microbes directly inhabit the contaminated substrate and are responsible for many of the soil reactions that allow for a self-sustaining vegetative cover. Measuring microbial diversity and function is increasingly common in both lab and field studies. On a basic level, studies have measured respiration as an indication of an active microbial community [41, 49, 52, 57]. Total microbial biomass has also been measured [41, $42,68]$. Functionality measures include the ratio of $\mathrm{NH}_{4} /$ $\mathrm{NO}_{3}$, an indicator of the microbial ability to oxidize ammonia [1, 41] and nitrification [42]. Studies have also included quantification of microbial enzymes [42, 49, $52,58,68]$. There are also examples of tests of microbial diversity being used to assess the complexity of the restored systems in comparison to uncontaminated soils [51, 59, 69]. Pepper et al. [51] quantified the diversity in the microbial community in biosolid-amended $\mathrm{Cu}$ mine tailings in comparison to a control site and to untreated tailings. The group used DNA extraction followed by PCR amplification to characterize the richness and diversity of the microbial community on the amended tailings. They found that the community in the treated tailings, 10 years posttreatment, was similar in microbial number, activity, and diversity to native soils. As genetic tools to analyze microbial populations in soil become increasingly common, it is likely that this type of analysis will be used more frequently to assess ecosystem function in restored sites [51, 70]. 
Table 3 Measures to assess reduction in bioavailability as a result of amendment addition and ecosystem function in amended systems

\begin{tabular}{|c|c|c|c|c|c|}
\hline Study & Soil extracts & Microbial assays & Soil biota & Plant measures & Mammal \\
\hline Baker et al. [42] & $\begin{array}{l}\mathrm{Ca}\left(\mathrm{NO}_{3}\right)_{2} \text { extractable } \\
\text { metals, DGT metals }\end{array}$ & $\begin{array}{l}\text { Total microbial biomass, } \\
\text { phospholipid fatty acid (PLFA) } \\
\text { followed by fatty acid methyl } \\
\text { esters (FAME), nitrification using } \\
\text { aerobic incubation, enzyme assays } \\
\text { including B-glucosidase, acid } \\
\text { phosphatase, alkaline } \\
\text { phosphatase, and arylsulfatase }\end{array}$ & & & \\
\hline Brown et al. [43] & $\begin{array}{l}\mathrm{Ca}\left(\mathrm{NO}_{3}\right)_{2} \text { extractable } \\
\quad \text { metals }\end{array}$ & & & $\begin{array}{l}\text { Plant } \mathrm{Cd}, \mathrm{Pb}, \mathrm{Zn} \\
\text { concentrations, } \\
\text { biomass }\end{array}$ & \\
\hline Brown et al. [41] & $\begin{array}{l}\text { Water soluble, weak } \\
\text { acid extractable, } \\
\text { exchangeable, and } \\
\text { TCLP metals }\end{array}$ & $\begin{array}{l}\text { Microbial biomass } \mathrm{C} \\
\text { and } \mathrm{N}, \mathrm{CO}_{2}-\mathrm{C} \\
\text { respiration and } \\
\mathrm{NH}_{4} / \mathrm{NO}_{3} \text { ratio }\end{array}$ & $\begin{array}{l}\text { Earthworm survival } \\
\text { and metal uptake }\end{array}$ & $\begin{array}{l}\text { Plant } \mathrm{Cd}, \mathrm{Pb}, \mathrm{Zn} \\
\text { concentrations }\end{array}$ & $\begin{array}{l}\text { Small mammal } \\
\text { number and whole } \\
\text { body } \mathrm{Cd}, \mathrm{Pb} \text {, and } \mathrm{Zn} \\
\text { concentrations }\end{array}$ \\
\hline Brown et al., [44] & $\begin{array}{l}\mathrm{NH}_{4} \mathrm{NO}_{3} \text { extractable } \\
\text { metals, extractable } \\
\mathrm{Fe} \text { and } \mathrm{Al}\end{array}$ & & & $\begin{array}{l}\text { Plant Cd Zn } \\
\text { concentrations }\end{array}$ & PBET \\
\hline Trlica and Brown [45] & & & & $\begin{array}{l}\text { Plant } \mathrm{Cd} \text { and } \mathrm{Zn} \\
\text { concentrations }\end{array}$ & \\
\hline Brown et al. [46] & $\begin{array}{l}\mathrm{Ca}(\mathrm{NO} 3) 2 \text { extractable } \\
\text { metals }\end{array}$ & & & $\begin{array}{l}\text { Plant } \mathrm{Cd} \text { and } \mathrm{Zn} \\
\text { concentrations }\end{array}$ & \\
\hline Brown et al. [1] & $\begin{array}{l}\mathrm{Ca}\left(\mathrm{NO}_{3}\right)_{2} \text { extractable } \\
\text { metals }\end{array}$ & $\mathrm{NH}_{4} / \mathrm{NO}_{3}$ ratio & $\begin{array}{l}\text { Earthworm survival } \\
\text { and metal uptake }\end{array}$ & $\begin{array}{l}\text { Plant } \mathrm{Cd} \text { and } \mathrm{Zn} \\
\text { concentrations }\end{array}$ & $\begin{array}{l}\text { Small mammal number } \\
\text { and kidney } \mathrm{Cd}, \mathrm{Pb} \text {, } \\
\text { and } \mathrm{Zn} \text { concentrations }\end{array}$ \\
\hline Cordova et al. [47] & $\begin{array}{l}0.1 \mathrm{KNO}_{3} \text { extractable } \\
\quad \mathrm{Cu}, \mathrm{Cu}^{2+} \text { ion activity }\end{array}$ & & & & \\
\hline Friesl-Hanl et al. [48] & $\begin{array}{l}1 \mathrm{M} \mathrm{NH}_{4} \mathrm{NO}_{3} \text { extractable } \\
\text { metals, soil pore water } \mathrm{Zn}\end{array}$ & & & $\begin{array}{l}\text { Agronomic plant metal } \\
\text { concentrations in } \\
\text { grain and straw }\end{array}$ & \\
\hline Galende et al. [49] & $\begin{array}{l}\mathrm{CaCl}_{2} \text { extractable } \mathrm{Pb}, \mathrm{Zn}, \\
\text { root elongation assay }\end{array}$ & $\begin{array}{l}\text { Basal respiration, substrate-induced } \\
\text { respiration, enzyme activities } \\
\text { including b-glucosidase, } \\
\text { arylsulfatase, acid phosphatase, } \\
\text { urease, community level profiles } \\
\text { using Biolog EcoPlates }\end{array}$ & & & \\
\hline Madejón et al. [50] & $\begin{array}{l}\text { EDTA extractable, } \mathrm{CaCl}_{2} \\
\quad \text { extractable }\end{array}$ & & & & \\
\hline Pepper et al. [51] & & $\begin{array}{l}\text { Heterotrophic plate counts, bacterial } \\
\text { community DNA extraction with } \\
\text { PCR amplification, cloning and } \\
\text { sequencing of 16S r RNA used for } \\
\text { richness estimates and diversity } \\
\text { index, nitrification, sulfur } \\
\text { oxidation, and dehydrogenase }\end{array}$ & & & \\
\hline Stuczynski et al. [52] & $\begin{array}{l}\text { De-Ionized water } \\
\text { extractable } \mathrm{Cd}, \\
\mathrm{Pb} \text {, and } \mathrm{Zn}\end{array}$ & $\begin{array}{l}\text { Glucose induced respiration, total } \\
\text { respiration, enzyme assays } \\
\text { including alkaline phosphatase, } \\
\text { acid phosphatase, urease, } \\
\text { arylsulfatase, and dehydrogenase }\end{array}$ & & $\begin{array}{l}\text { Grass yield and metal } \\
\text { concentration }\end{array}$ & $\begin{array}{l}\text { Feeding study with } \\
\text { calves fed with hay } \\
\text { grown on the treated } \\
\text { materials }\end{array}$ \\
\hline Ulriksen et al. [53] & $\begin{array}{l}\text { De-ionized water and } \\
\mathrm{KNO}_{3} \text {-extractable } \\
\mathrm{Cu}\end{array}$ & & & $\begin{array}{l}\text { Plant tissue } \mathrm{Cu} \text {, } \\
\mathrm{As}, \mathrm{Zn} \text { and } \mathrm{Pb} \\
\text { concentrations }\end{array}$ & \\
\hline $\begin{array}{c}\text { Vangronsveld } \\
\text { et al. [54] }\end{array}$ & Water extractable metals & & & $\begin{array}{l}\text { Plant growth and } \\
\text { morphological } \\
\text { parameters, plant } \\
\text { enzyme assays }\end{array}$ & \\
\hline
\end{tabular}

\section{Soil Biota}

On the next level, population counts and diversity of soil biota have been quantified on treated contaminated sites soils [41,
71]. Bouwman and Vangronsveld [71] measured nematode populations at a $\mathrm{Zn}$ smelter 12 years after a metalimmobilizing agent (cyclonic ash), and a municipal waste compost had been added to the site and found that 27 species 
of nematodes were present in the amended soils. However, a number of species that were commonly found on neighboring uncontaminated sites were not found on the restored soil, suggesting that only partial function had been restored. A shift in nematodes might have resulted in the raised $\mathrm{pH}$ of the remediated site (required to prevent $\mathrm{Zn}$ phytotoxicity) compared to nearly uncontaminated very acidic soils, so comparisons must consider the multiple changes in soils when remediation is required. This type of assay is only possible for field trials. Earthworm assays, based on survival and or survival and metal accumulation, can be used for field studies as well as laboratory incubated materials $[1,41,62]$. Brown et al. [1, 41] studied earthworm survival and metal uptake on treated tailings and found that amendments reduced toxicity and resulted in increased biomass. Results from earthworm assays can also be used to estimate the potential for contaminant transfer through the wildlife food chains $[36,41]$.

\section{Mammals}

One of the concerns with in situ amendments is that restoring vegetative cover on sites will result in creating an "attractive nuisance." Animals will return to the sites and be exposed to contaminants, effectively increasing the hazard posed by the contaminants. Brown et al. [1, 41] trapped small mammals and measured whole body and kidney concentrations of $\mathrm{Cd}$, $\mathrm{Pb}$, and $\mathrm{Zn}$. Kidney pathology was also examined to determine if exposure to contaminants had resulted in damage to this organ. Results showed that amendments had restored sites sufficiently to attract high populations of small mammals and that damage to organs was only observed in a small minority of the animals that were captured. This type of study is expensive and is only possible on large-scale field trials. Vangronsveld [54] reported evidence of rabbits returning to the restored site but did not assess impacts to small mammals.

This brief summary suggests that a range of measures can be used to assess reduction in contaminant availability at metal mining-impacted sites where amendments have been used to reduce metal availability and restore ecosystem function. While a range of soil extractions have been used and typically show reduced extractable metals with certain amendments, this alone is not sufficient to demonstrate a reduction in toxicity. Kumpiene et al. [62] found high correlations between reduced extractable metals and other ecosystem endpoints in a controlled study using soils from a range of sites. Brown et al. [57] also reported a relationship between extractable metals and plant response for a range of amendments tested on a single soil in a multilaboratory study. Relationships have also been seen with reduced extractable metals and increased microbial function and populations [42]. Mild extractions similar to soil solution $\left(0.01 \mathrm{M} \mathrm{Ca}\left(\mathrm{NO}_{3}\right)_{2}\right.$ or $\left.1 \mathrm{M} \mathrm{NH}_{4} \mathrm{NO}_{3}\right)$ are much better predictors of metal remediation for plants than are strong extractants (DTPA), and higher solution/soil ratios are required to avoid saturation of chelating extractants [27]. Measures of microbial populations, activity, and diversity are likely to become more common with increased availability of tools to measure these variables. Plant assays are also frequently used and appear to be effective for demonstrating reductions in bioavailability, particularly when native rather than metal-tolerant species are tested. Testing efficacy higher up on the food chain will likely be limited due to associated costs and the need for larger-scale field trials. However, this type of approach may be helpful for regulatory acceptance.

\section{Soil fertility and Physical Properties}

For amended sites to have full ecological function, it is critical that the treated site soils can function as living soils. This involves both the ability of the substrate to supply required plant nutrients over the long-term as well as having the necessary physical characteristics to support plant growth. There are also a range of tests and accepted protocols to measure soil fertility and soil physical properties (phytoavailable metals; nutrients; salinity; SAR; $\mathrm{Ca} / \mathrm{Mg}$ ratio, etc.). Despite this, not all studies include these measures. For example, while Kumpiene et al. [62] tested a set of measures to assess the efficacy of different GROs, no measures related to soil function, fertility, or physical properties were included. Some of the field tests of amendments have included at least a portion of these measures (Table 4). Changes in soil physical properties would include changes in bulk density, water holding capacity, texture, and organic matter or total C. While soil carbon and organic matter are not technically physical properties, there is a direct relationship between soil organic matter content and soil quality [72] Use of organic amendments and increased soil $\mathrm{C}$ has also been associated with improved soil physical properties including increased water holding capacity and reduced bulk density $[73,74]$. Many of the field studies included measures of soil organic matter or soil carbon. A few studies have included measures of soil water holding capacity after amendment addition [1, 47, 53] (Fig. 2). Increased water holding capacity was observed with organic matter amendment addition for each of these studies. Newly established plant cover will be more resilient if plants are not subject to drought stress. It would appear that increased water holding capacity would increase the potential for long-term success. Brown et al. also measured bulk density and found reduced bulk density $\left(0.82 \mathrm{~g} \mathrm{~cm}^{3}\right)$ on sites where high rates of biosolids had been applied in comparison to the untreated tailings $\left(1.52 \mathrm{~g} \mathrm{~cm}^{3}\right)$.

Most of the field studies included measures of soil $\mathrm{pH}$ (Table 4). Soil $\mathrm{pH}$ is a critical variable for metalcontaminated sites as $\mathrm{pH}$ is a major factor controlling the solubility and availability of metals to many receptors. Increasing $\mathrm{pH}$ will decrease the solubility of most metals to 
Table 4 Measures of soil fertility, physical properties, and plant nutrient concentrations on field sites restored using a combination of amendments

\begin{tabular}{|c|c|c|c|}
\hline Study & Soil nutrients & Soil physical properties & Plant nutrients \\
\hline Baker et al. [42] & $\mathrm{pH}, \mathrm{NH}_{4}-\mathrm{N}, \mathrm{NO}_{3}-\mathrm{N}, \mathrm{P}, \mathrm{K}$ & Total C & \\
\hline Brown et al. [44] & $\mathrm{pH}, \mathrm{EC}$ & Total C & \\
\hline Trlica and Brown [45] & $\mathrm{C}: \mathrm{N}$ ratio & & \\
\hline Brown et al. [46] & $\mathrm{pH}, \mathrm{EC}$ & & \\
\hline Brown et al. [1] & Mehlich III Cu, K, P, total N & $\begin{array}{l}\text { Organic } \mathrm{C} \text {, Bulk density, } \\
\qquad \% \mathrm{H}_{2} \mathrm{O} \text { at } 1 \text { bar, texture }\end{array}$ & \\
\hline Cordova et al. [47] & $\mathrm{EC}, \mathrm{pH}, \mathrm{N}, \mathrm{P}, \mathrm{K}, \mathrm{Ca}, \mathrm{Mg}$ & $\mathrm{OM} \%$, Field capacity $(\% \mathrm{w} / \mathrm{w})$ & $\begin{array}{l}\text { Plant concentrations of nutrients: } \\
\text { N, P, K, Ca, Mg, Zn, Mn, Fe }\end{array}$ \\
\hline Friesl-Hanl et al. [48] & $\mathrm{pH}, \mathrm{EC}, \mathrm{CEC}$ & Texture, organic $\mathrm{C}$ & $\begin{array}{l}\text { Plant concentrations of nutrients: } \\
\mathrm{Cu}, \mathrm{Mn}, \mathrm{Mg} \text {, and } \mathrm{P}\end{array}$ \\
\hline Galende et al. [49] & $\begin{array}{l}\mathrm{pH}, \mathrm{CEC} \text {, available } \mathrm{P} \text {, total } \mathrm{N} \text {, } \\
\text { exchangeable } \mathrm{K}, \mathrm{Ca} \text {, and } \mathrm{Mg}\end{array}$ & Texture, organic matter & \\
\hline Madejón et al. [50] & $\mathrm{pH}$, total S & Organic $\mathrm{C}$ & $\begin{array}{l}\text { Plant concentrations of } \\
\text { macronutrients: } \mathrm{N}, \mathrm{K}, \mathrm{P}, \mathrm{Ca} \text {, } \\
\mathrm{S}, \mathrm{Mg}, \mathrm{Mn}\end{array}$ \\
\hline Stuczynski et al. [52] & $\mathrm{pH}$ and $\mathrm{EC}$ & & \\
\hline Ulriksen et al. [53] & Available N, P, K, Ca and $\mathrm{Mg}, \mathrm{EC}$ & $\begin{array}{l}\% \text { OM, soil water holding } \\
\text { capacity }\end{array}$ & \\
\hline Vangronsveld et al. [54] & CEC, $\mathrm{pH}$ & $\mathrm{OM}$ & \\
\hline
\end{tabular}

plants and also reduce extractable metal concentrations. In contrast, increasing $\mathrm{pH}$ can increase availability and solubility of metalloids ( $\mathrm{Se}, \mathrm{Mo}$ ). Soil $\mathrm{pH}$ is also a factor in determining the availability of many plant nutrients and so measures of soil $\mathrm{pH}$ were considered here to be a measure of soil fertility. Electrical conductivity (EC) is another parameter that will impact access to nutrients and the sustainability of in situ amendments. Particularly in arid areas, amendments with high EC can limit plant response even if contaminant availability is reduced $[46,52]$. Thus, irrigation may be required to remove

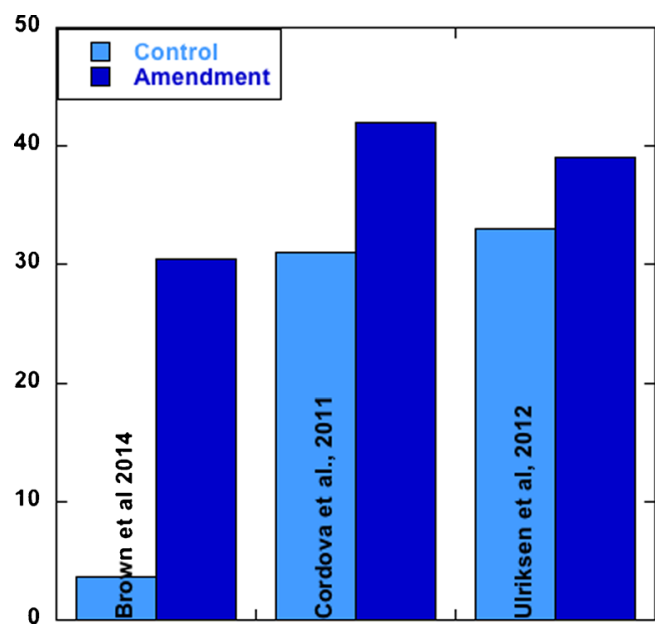

Fig. 2 Reported changes in soil water holding capacity following amendment addition from field trials. Brown et al. [1] measured percent $\mathrm{H} 2 \mathrm{O}$ at 0.1 bar, Cordova et al. [47] measured percent $\mathrm{H}_{2} \mathrm{O} w / w$, and Ulriksen et al. [53] measured percent water holding capacity. All observed changes were statistically significant excessive salinity [26], or a capillary breaking layer installed below improved topsoil [52].

More traditional measures of soil fertility include extractions to measure available soil nutrients as well as plant digests to assess nutrient concentrations in plant tissue. Several of the studies included one or both of these measures (Table 4). In mine waste-impacted materials, in addition to metal toxicities, nutrient deficiencies can be a limiting factor for plant growth. Use of organic amendments to restore soil function should include a consideration of the required macronutrients and micronutrients for plant growth. As the importance of and potential for establishing these sites as functional ecosystems is increasingly recognized, it is likely that traditional measures of soil fertility, quality, and productivity will be included in tools to evaluate amendment mixtures and remedial options. Long-term sites where disturbance rather than metal contamination was the primary factor limiting plant growth (e.g., coal mine sites) have shown that amendments are sufficient to reestablish productivity $[19,45]$. It is likely that similar results will be seen with the appropriate use of amendments.

\section{Ecosystem Services}

\section{Community Diversity}

All of the field trials listed in Table 4 have shown the ability of amendments to limit contaminant availability, improve fertility, and restore a plant cover to treated materials. The restored systems appear able to support plant life that is typical for the particular region rather than only metal or salt-tolerant 
ecotypes [41, 50, 54, 75]. Córdova et al. [47] measured plant species diversity, percent cover, and biomass in $\mathrm{Cu}$ mining impacted materials amended with compost and limestone. Two revegetation techniques were tested in the trial: spontaneous and assisted revegetation. The researchers found that the native seed bank was sufficient to establish a native cover on the amended soils. Brown et al. [75] altered the $\mathrm{C} / \mathrm{N}$ ratio of amendments through different ratios of municipal biosolids and woody material on alluvial $\mathrm{Pb}$ and $\mathrm{Zn}$ tailings in Leadville, CO. Plots were seeded with a mixture of native plants. Species diversity and percent cover were measured 1 , 2 , and 5 years after amendment addition. The treatment that had the lowest $\mathrm{C} / \mathrm{N}$ ratio (8:1) had the highest biomass at year 5 as well as the lowest diversity. Results indicated that a $\mathrm{C} / \mathrm{N}$ ratio greater than 20:1 resulted in increased species diversity. Vangronsveld et al. [54] observed multiple types of fungi on a high metal mine waste area amended with cyclonic ash and compost. The authors also noted evidence of animal browsing. Small mammal return to amended sites was also reported by Brown et al. [1, 41]. These results suggest that appropriately used amendments can restore ecosystem functions to the impacted areas.

\section{Quantification of Value}

To date, quantification of ecosystem services on restored sites has been limited $[1,76]$. These benefits can include a range of ecosystem services such as nutrient and waste recycling and carbon sequestration. There is also a potential for social benefits such as increased open space and associated recreation opportunities. Finally, there are a range of economic benefits including agricultural production and biomass generation. Many of these benefits have been realized at disturbed noncontaminated sites restored with residuals. For example, high rates of carbon sequestration have been observed on sites reclaimed with organic residuals in comparison to sites restored with topsoil or fertilizer [19, 45, 77]. US EPA sampled contaminated sites restored with amendments to quantify soil carbon restoration [76]. At Leadville, CO, EPA quantified soil carbon storage at a number of sites where biosolids or compost and limestone equivalent had been applied to highly acidic (pH 3.5 due to sulfide oxidation) $\mathrm{Pb}-\mathrm{Zn}$ alluvial tailings to reduce metal toxicity 10 years prior. Unamended tailings were used as a reference point. They found net carbon sequestration of 52-86 t C ha ${ }^{-1}$, equivalent to $190-315 \mathrm{t} \mathrm{CO}_{2} \mathrm{ha}^{-1}$ in the amended sites. Brown et al. [1] compared the ecosystem impacts of the use of amendments to restore $\mathrm{Pb}$ and $\mathrm{Zn}$ mine wastes to topsoiling. The cost of using harvested topsoil to cover contaminated materials was estimated by calculating the time required to build $15 \mathrm{~cm}$ of topsoil and the per hectare price paid to farmers to leave sensitive land fallow under the USDA Conservation Reserve Program. In comparison, the greenhouse gas costs and benefits of using municipal biosolids including avoided emissions of fugitive gasses, transport emissions, fertilizer credits, and soil carbon sequestration were calculated. The authors estimated that it would require 1875 years to replace $15 \mathrm{~cm}$ of topsoil resulting in a cost of US $\$ 241,070$ per hectare. In contrast, diverting biosolids from incineration to land application for the same amount of land would result in avoidance of $485 \mathrm{t}$ of $\mathrm{CO}_{2}$ and an additional credit of $-156 \mathrm{t} \mathrm{CO}_{2}$.

\section{Conclusion}

Use of amendments to reduce metal availability and increase soil function appears to be transitioning from laboratory scale to field trial and full-scale use. A range of tools exists to measure success of these efforts and can be used to assess functioning of these systems on multiple levels. Full valuation of the benefits of this type of approach, however, is still being developed.

Acknowledgments Authors acknowledge support from US-EPAOffice of Superfund Remediation and Technology Innovation under an Interagency Agreement between EPA and USDA-ARS and a Specific Cooperative Agreement between USDA-ARS and University of Washington.

\section{Compliance with Ethical Standards}

Conflict of Interest On behalf of all authors, the corresponding author states that there is no conflict of interest

\section{References}

1. Brown S, Mahoney M, Sprenger M. A comparison of the efficacy and ecosystem impact of residuals-based and topsoil-based amendments for restoring historic mine tailings in the Tri-State mining district. Sci Total Environ. 2014;485-486:624-32.

2. Haering KC, Daniels WL, Feagley SE. Reclaiming mined lands with biosolids, manures, and papermill sludges. In: Barnhisel RI, Darmody RG, Daniels WL, editors. Reclamation of drastically disturbed lands. Agron. Monogr. 41. Madison: ASA and SSSA; 2000. p. 615-44.

3. Sopper WE. Municipal sludge use in land reclamation. Boca Raton: Lewis; 1993. 163 pp.

4. Allen, HL, Brown SL, Chaney R, Daniels WL, Henry CL, Neuman DR, Rubin E, Ryan JA, Toffey W. The use of soil amendments for remediation, revitalization and reuse. US EPA. EPA 542-R-07-013 2007.

5. Patterson GL, Fuentes RF, Toler LG. Hydrologic characteristics of surface-mined land reclaimed by sludge irrigation, Fulton County, Illinois. USGS Water-Resources Investigations Open-File Rep. 8216. Reston: USGS, 1982.

6. Topper KF, Sabey BR. Sewage sludge as a coal mine spoil amendment for revegetation in Colorado. J Environ Qual. 1986;15:44-9. 
7. Bloomfield HE, Handley JF, Bradshaw AD. Nutrient deficiencies and the aftercare of reclaimed derelict land. J Appl Ecol. 1982;19: $151-8$.

8. U.S. Environmental Protection Agency. Part 503 Implementation Guidance, EPA 833-R-95-001. Washington: USEPA; 1995.

9. Granato TC, Pietz RI, Knafl GJ, Carlson Jr CR, Tata P, Lue-Hing C. Trace element concentrations in soil, corn leaves, and grain after cessation of biosolids applications. J Environ Qual. 2004;33:207889.

10. Hinesly TD, Redborg DE, Ziegler EL, Rose-Innes IH. Effects of chemical and physical changes in stripmined spoil amended with sewage sludge on the uptake of metals by plants. In: Sopper WE, Seaker EM, Bastian RK, editors. Land reclamation and biomass production with municipal wastewater and sludge. University Park: Pennsylvania State Univ. Press; 1982. p. 339-52.

11. Oladeju OO, Tian G, Cox AE, Granato TC, Pietz RI, Carlson CR, et al. Effects of long-term application of biosolids for mine land reclamation on groundwater chemistry: trace metals. J Environ Qual. 2012;41:1445-51.

12. Pond AP, White SA, Milczarek M, Thompson TL. Accelerated weathering of biosolid-amended copper mine tailings. J Environ Qual. 2005;34:1293-301.

13. Stehouwer R, Day RL, MacNeal KE. Nutrient and trace element leaching following mine reclamation with biosolids. J Environ Qual. 2006;35:1118-26.

14. Daniels WL, Evanylo GK, Nagle SM, Schmidt JM. Effects of biosolids loading rate and sawdust additions on row crop yield and nitrate leaching potentials in Virginia sand and gravel mine reclamation. In Barnhisel et al. editors. Proc. 18th Nat. Meeting Amer. Soc. Surf. Mining and Rec., Albuquerque. Amer. Soc. Surf. Mining and Rec., 3134 Montavesta Rd, Lexington, KY, 40502. pp. 399406.

15. Daniels WL, Evanylo GK, Nagle SM, Schmidt JM. Effects of biosolids loading rate on nitrate leaching potentials in sand and gravel mine reclamation in Virginia. 2003. WEFTEC.pp 271-278. doi:10. 2175/193864703784640596

16. Roberts JA, Daniels WL, Bell JC, Burger JA. Early stages of mine soil genesis as affected by topsoiling and organic amendments. Soil Sci Soc Am J. 1988;52:730-8.

17. Roberts JA, Daniels WL, Bell JC, Martens DC. Tall fescue production and nutrient status on Southwest Virginia Mine Soils. J Environ Qual. 1988;17:55-62.

18. DanielsWL, Orndorff ZW. Indicators of reclamation success for mineral sands mining in the USA. In Proc. 6th Int. Conf. Sustainable Development in the Minerals Industry. Greece: Milos island: 2013. Pp 226-231.

19. Tian G, Granato TC, Cox AE, Pietz RI, Carlson CR, Abedin Z. Soil carbon sequestration resulting from long-term application of biosolids for land reclamation. J Environ Qual. 2009;38:61-74.

20. Norman DK, Wampler PJ, Throop AH, Schnitzer EF, Roloff JM. Best management practices for reclaiming surface mines in Washington and Oregon. Washington Division of Geology and Earth Resources Washington Department of Natural Resources. Open File Report; 1997. 96-2.

21. VDMME, 1995. Virginia Dept. Of Mines, Minerals and Energy, Div. of Mined Land Rec. Guidelines for use of biosolids on DMME/DMLR Permits; VDMLR, Drawer U, Big Stone Gap, VA, $10 \mathrm{p}$.

22. Mench M, Schwitzguébel JP, Schroder P, Bert V, Gawronski S, Gupta S. Assessment of successful experiments and limitations of phytotechnologies: contaminant uptake, detoxification and sequestration, and consequences for food safety. Environ Sci Pollut Res. 2009;16:876-900.

23. Tordoff GM, Baker AJM, Willis AJ. Current approaches to the revegetation and reclamation of metalliferous mine wastes. Chemosphere. 2000;41:219-28.
24. Vangronsveld J, Herzig R, Weyens N, Boulet J, Adriaensen K, Ruttens A, et al. Phytoremediation of contaminated soils and groundwater: lessons from the field. Environ Sci Pollut Res. 2009;16:765-94.

25. Wong MH. Ecological restoration of mine degraded soils, with emphasis on metal contaminated soils. Chemosphere. 2003;50: 775-80.

26. Mendez MO, Maier RM. Phytostabilization of mine tailings in arid and semiarid environments - an emerging remediation technology. Environ Health Perspect. 2008;116:278-83.

27. Li YM, Chaney RL, Siebielec G, Kerschner BA. Response of four turfgrass cultivars to limestone and biosolids-compost amendment of a zinc and cadmium contaminated soil at Palmerton. Pennsylvania. J Environ Qual. 2000;29:1440-7.

28. Matthews DJ, Moran BM, Otte ML. Screening the wetland plant species Alisma plantago-aquatica, Carex rostrata and Phalaris arundinacea for innate tolerance to zinc and comparison with Eriophorum angustifolium and Festuca rubra Merlin. Environ Pollut. 2005;134:343-51.

29. Wong MH. Metal co-tolerance to copper, lead and zinc in Festuca rubra. Environ Res. 1982;29:42-7.

30. Smith RAH, Bradshaw AD. The use of metal tolerant plant populations for the reclamation of metalliferous wastes. J Appl Ecol. 1979; 16:595-612.

31. Porter SK, Scheckel KG, Impellitteri CA, Ryan JA. Toxic metals in the environment: thermodynamic considerations for possible immobilization strategies for $\mathrm{Pb}, \mathrm{Cd}, \mathrm{As}$, and $\mathrm{Hg}$. Crit $\mathrm{Rev}$ Environ Sci Technol. 2004;34:495-604.

32. Ryan JA, Berti WR, Brown SL, Casteel SW, Chaney RL, Doolan $\mathrm{M}$, et al. Reducing children's risk to soil lead: summary of a field experiment. Environ Sci Technol. 2004;38:19A-24A.

33. Jacquat O, Voegelin A, Kretzschmar R. Soil properties controlling Zn speciation and fractionation in contaminated soils. Geochim Cosmochim Acta. 2009;73:5256-72.

34. Van Damme A, Degryse F, Smolders E, Sarret G, Dewit J, Swennen $\mathrm{R}$, et al. Zinc speciation in mining and smelter contaminated overbank sediments by EXAFS spectroscopy. Geochim Cosmochim Acta. 2010;74:3707-20.

35. Brown SL, Clausen I, Chappell MA, Williams A, Scheckel KG, Neuville M, et al. Lead and As speciation and bioaccessibility in compost amended contaminated soils. J Environ Qual. 2012;41: 1612-22.

36. Brown SL, Chaney R, Sprenger M, Compton H. Assessing impact to wildlife at biosolids remediated sites. BioCycle. 2002;43(8):50-8.

37. Volchko Y, Norrman J, Bergknut M, Rosén L, Söderqvist T. Incorporating the soil function concept into sustainability appraisal of remediation alternatives. J Environ Manag. 2013;129:367-76.

38. Volchko Y, Norrman J, Rosén L, Bergknut M, Josefsson S, Söderqvist $\mathrm{T}$, et al. Using soil function evaluation in multi-criteria decision analysis for sustainability appraisal of remediation alternatives. Sci Total Environ. 2014;485-486:785-91.

39. Cundy AB, Bardos RP, Church A, Puschenreiter M, Friesl-Hanl W, Müller I, et al. Developing principles of sustainability and stakeholder engagement for "gentle" remediation approaches: The European context. J Environ Manag. 2013;129:283-91.

40. Munns WR, Rea AW, Suter GW, Martin L, Blake-Hedges L, Crk T, et al. Ecosystem services as assessment endpoints for ecological risk assessment. Integr Environ Assess Manag. 2016. doi:10. 1002/ieam.1707.

41. Brown S, Sprenger M, Maxemchuk A, Compton H. An evaluation of ecosystem function following restoration with biosolids and lime addition to alluvial tailings deposits in Leadville. CO. J Environ Qual. 2005;34:139-48.

42. Baker LR, White PM, Pierzynski GM. Changes in microbial properties after manure, lime, and bentonite application to a heavy metal-contaminated mine waste. Appl Soil Ecol. 2011;48:1-10. 
43. Brown S, Henry CL, Chaney RL, Compton H, DeVolder PS. Using municipal biosolids in combination with other residuals to restore metal-contaminated mining areas. Plant Soil. 2003;249:203-15.

44. Brown S, Compton H, Basta N. Field test of in situ soil amendments at the Tar Creek National Priorities List Superfund Site. J Environ Qual. 2007;36:1627-34.

45. Trlica A, Brown S. Greenhouse gas emissions and the interrelation of urban and forest sectors in reclaiming one hectare of land in the Pacific Northwest. Environ Sci Technol. 2013;47:7250-9.

46. Brown S, Svendson A, Henry C. Restoration of high zinc and lead tailings with municipal biosolids and lime: field study. J Environ Qual. 2009;38:2189-97.

47. Córdova S, Neaman A, González I, Ginocchio R, Fine P. The effect of lime and compost amendments on the potential for the revegetation of metal-polluted, acidic soils. Geoderma. 2011;166:135-44.

48. Friesl-Hanl W, Platzer K, Horak O, Gerzabek MH. Immobilising of $\mathrm{Cd}, \mathrm{Pb}$, and $\mathrm{Zn}$ contaminated arable soils close to a former $\mathrm{Pb} / \mathrm{Zn}$ smelter: a field study in Austria over 5 years. Environ Geochem Health. 2009;31:581-94.

49. Galende MA, Becerril JM, Barrutia O, Artetxe U, Garbisu C, Hernández A. Field assessment of the effectiveness of organic amendments for aided phytostabilization of a $\mathrm{Pb}-\mathrm{Zn}$ contaminated mine soil. J Geochem Explor. 2014;145:181-9.

50. Madejón E, Pérez de Mora A, Felipe E, Burgos P, Cabrera F. Soil amendments reduce trace element solubility in a contaminated soil and alow regrowth of natural vegetation. Environ Pollut. 2006;139: 40-52.

51. Pepper IL, Zerzghi HG, Bengson SA, Iker BC, Manerjee MJ, Brooks JP. Bacterial populations within copper mine tailings: long-term effects of amendment with class A biosolids. J Appl Microbiol. 2012;113:569-77.

52. Stuczynski T, Siebielec G, Daniels WL, McCarty G, Chaney RL. Biological aspects of metal waste reclamation with biosolids. J Environ Qual. 2007;36:1154-62.

53. Ulriksen C, Ginocchio R, Mench M, Neaman A. Lime and compost promote plant re-colonization of metal-polluted, acidic soils. Int $\mathrm{J}$ Phytoremediation. 2012;14:820-33.

54. Vangronsveld J, Colpaert JV, Van Tichelen KK. Reclamation of a bare industrial area contaminated by non-ferrour metals: physicochemical and biological evaluation of the durability of soil treatment and revegetation. Environ Pollut. 1996;94:131-40.

55. National Research Council, Luthy R, Allen-King R, Brown S, Dzombak D, Fendorf S, et al. Bioavailability of contaminants in soils and sediments. Washington: National Academy of Sciences; 2003. $420 \mathrm{p}$.

56. Costanza R, d'Arge R, de Groot R, Farber S, Grasso MM, Hannon $\mathrm{B}$, et al. The value of the world's ecosystem services and natural capital. Nature. 1997;387:253-60.

57. Brown S, Christensen B, Lombi E, McLaughlin M, McGrath S, Colpaert J, et al. An Inter-laboratory study to test the ability of amendments to reduce the availability of $\mathrm{Cd}, \mathrm{Pb}$, and $\mathrm{Zn}$ in-situ. Environ Pollut. 2005;138:34-45.

58. Pérez de Mora A, Ortega-Calvo JJ, Cabrera F, Madejón E. Changes in enzyme activities and microbial biomass after "in situ" remediation of a heavy metal-contaminated soil. Appl Soil Ecol. 2005;28:125-37.

59. Rosario K, Iverson SL, Henderson DA, Chartrand S, McKeon C, Glenn EP, et al. Bacterial community changes during plant establishment at the San Pedro river mine tailings site. J Environ Qual. 2007;36:1249-59.
60. US EPA Method 311 toxicity characteristic leaching procedurehttp://www3.epa.gov/epawaste/hazard/testmethods/ sw846/pdfs/1311.pdf

61. O'Connor GA. Use and misuse of the DTPA soil extract. J Environ Qual. 1988;17:715-8.

62. Kumpiene J, Bert V, Dimitriou I, Eriksson J, Friesl-Hanl W, Galazka R, et al. Selecting chemical and ecotoxicological test batteries for risk assessment of trace elment-contaminated soils (phyto) managed by gentle remediation options (GMO). 2014. Sci Total Environ. 2014;496:510-22.

63. DeVolder P, Brown SL, Hesterberg D, Pandya K. Metal bioavailability and speciation in a wetland tailings repository amended with biosolids compost, wood ash, and sulfate. J Environ Qual. 2003;32: $851-64$.

64. Furman O, Stawn DG, Heinz GH, Williams B. Risk assessment test for lead bioaccessibility to waterfowl in mine-impacted soils. J Environ Qual. 2006;35:450-8.

65. Beyer WN, Basta NT, Chaney RL, Henry PF, Mosby D BA, Rattner KG, Scheckel D, Sprague J, Weber. Bioaccessibility tests accurately estimate bioavailability of lead to quail. In preparation 2016.

66. Bourret MM, Brummer JE, Leininger WC. Establishment and growth of two willow species in a riparian zone impacted by mine tailings. J Environ Qual. 2008;38:693-701.

67. Chaney RL, Stoewsand GS, Furr AK, Bache CA, Lisk DJ. Elemental content of tissues of Guinea pigs fed Swiss chard grown on municipal sewage sludge-amended soil. J Agric Food Chem. 1978;26:944-97.

68. Pérez de Mora A, Burgos P, Madejóon E, Cabrera F, Jaeckel P, Schloter M. Microbial community structure and function in a soil contaminated by heavy metals: effects of plant growth and different amendments. Soil Biol Biochem. 2006;38:327-41.

69. Mummey DL, Stahl PD, Buyer JS. Soil microbiological properties 20 years after surface mine reclamation: spatial analysis or reclaimed and undisturbed sites. Soil Biol Biochem. 2002;34: 1717-25.

70. Bertagnolli AD, McCalmont D, Meinhardt KA, Fransen SC, Strand $\mathrm{S}$, Brown S, et al. Agricultural land usage transforms nitrifier population ecology. Environ Microbiol. 2016. doi:10.1111/1462-2920. 1311477. Bloomfield et al., 1982.

71. Bouwman L, Vangronsveld J. Rehabilitation of the nematode fauna in a phytostabilized heavily zinc contaminated sandy. J Soils Sediments. 2004;4:17-23.

72. Doran J. Soil health and global sustainability: translating science into practice. Agric Ecosyst Environ. 2002;88:119-27.

73. Brown S, Kurtz K, Bary A, Cogger C. Quantifying benefits associated with land application of organic residuals in Washington State. Environ Sci Technol. 2011;45:7451-8.

74. Khaleel R, Reddy KR, Overcash MR. Changes in soil physical properties due to organic waste applications: a review. J Environ Qual. 1981;10:133-41.

75. Brown S, DeVolder P, Henry C. Effect of amendment C:N ratio on plant diversity, cover and metal content for acidic $\mathrm{Pb}$ and $\mathrm{Zn}$ mine tailings in Leadville, CO. Environ Pollut. 2007;149:165-72.

76. US EPA. Terrestrial carbon sequestration Analysis of terrestrial carbon sequestration at three contaminated sites remediated and revitalized with soil amendments EPA-542-R-10-003 2011. https://clu-in. org/download/techdrct/Terrestrial-Carbon-Sequestration-Report.pdf

77. Wick AF, Daniels WL, Orndorff ZW, Alley MM. Organic matter accumulation post-mineral sands mining. Soil Use Manag. 2013;29:354-64. 